\title{
Cutting Energy Assessment of Selected Biomass Materials as Feedstock for Gasification
}

\author{
H. Manjunath ${ }^{1}$, Vijayakumar Palled ${ }^{1 *}$, M. Veerangouda ${ }^{2}$, \\ Devanand Maski ${ }^{1}$ and C.T. Ramachandra ${ }^{3}$
}

\author{
${ }^{1}$ Department of REE, CAE, Raichur, India \\ ${ }^{2}$ Department of Farm Machinery and Power Engineering, College of Agricultural \\ Engineering, UAS Raichur, Karnataka-584104, India \\ ${ }^{3}$ Department of Ag. Engg., CAE, UAS, Bangalore, India
}

*Corresponding author

\section{Keywords}

Biomass material, Bulk density, Calorific value, Cutting capacity, Energy requirement and Volatile matter content

\section{Article Info}

Accepted:

10 May 2019

Available Online:

10 June 2019
A B S T R A C T

Energy requirement for cutting of different biomass materials depends on their properties and size which plays an important role in gasification process. In present study, the cutting energy required by the size reduction machine to cut selected different biomass materials viz., Pigeon pea stalk (Cajanus cajan), Cotton stalk (Gossypium hirsutum) and vilatyee babool (Prosopis juliflora) into different length of sizes viz., 25-50, 50-75 and 75-100 mm was assessed. And also their physico-chemical and thermal properties were determined using the standard procedure. The cutting capacity of different biomass material ranged from 21.35 to $32.13,15.52$ to 24.12 and 25.04 to $39.40 \mathrm{~kg} \mathrm{~h}^{-1}$ respectively for pigeon pea stalk, cotton stalk and vilaytee babool. Whereas, the energy requirement for cutting into selected sizes $(25-50,50-75$ and $75-100 \mathrm{~mm})$ ranged from 0.21 to $0.07,0.16$ to 0.07 and 0.14 to $0.04 \mathrm{MJ} \mathrm{kg}^{-1}$ respectively. The moisture content of different biomass material ranged from 3.28 to 9.45 per cent and maximum bulk density of $556 \mathrm{~kg} \mathrm{~m}^{-3}$ was observed for vilaytee babool, followed by pigeon pea stalk $\left(501 \mathrm{~kg} \mathrm{~m}^{-3}\right)$ and minimum of $465 \mathrm{~kg} \mathrm{~m}^{-3}$ for cotton stalk. Whereas, maximum volatile matter content of 80.81 per cent was observed for vilaytee babool and a minimum of 80.20 per cent for cotton stalk. The calorific value of $16.44,16.05$ and $17.49 \mathrm{MJ} \mathrm{kg}^{-1}$ was observed for pigeon pea, cotton stalk and vilaytee babool, respectively.

\section{Introduction}

Agricultural and forest biomass material are a major part of crop residues and considered as important feed stocks for bioenergy applications as they have low nutritional value when used as feed for animals
(Tavakoli et al., 2009). The commonly available cereal straws are wheat, barley, and rice, and oat (Anon, 2000). There are some competing uses for these materials; for example, straw is sometimes used as feed or bedding for animals, or used as a soil amendment and incorporated into the 
ploughed layer or used as mulch. But both cereal and oilseed straws are finding use as feedstock for both thermo chemical and bioconversion applications. For all these applications, the size of these straws has to be reduced and particle size reduction is considered an important step in the conversion process. Particle size reduction of biomass is necessary, as the current biorefinery technologies cannot efficiently digest whole stems of grass and woody feed stocks. In addition, size-reduced biomass for direct combustion produces a more stable flame, high burnout, and low $\mathrm{CO}_{2}$ and ash emissions when compared to pellets and bales. Hess et al., (2007), Wu et al., (2007), Cundiff and Grisso (2008), Hess et al., (2009) and Wendt et al., (2008) indicated that the smaller biomass particles produced after size reduction have better digestibility in the conversion reactor than the raw material. Oasmaa et al., (2001), Wei et al., (2009) and Kumar et al., (2009) concluded that feedstock should be in particulate form for biorefinery pathways like hydrolysis, fermentation, gasification, pyrolysis, and chemical synthesis. Thus, many studies have been conducted in the last few years to understand the effect of varying particle sizes on conversion efficiency. For proper design and optimization of biomass size reduction equipment, it is necessary to know its mechanical properties. Power or energy requirements for size reduction of straw is one of these properties, and is influenced by initial particle size, moisture content, material properties, feed rate of the material, and machine variables (Mani et al., 2004). Tub grinders and hammer mills are the most commonly used pieces of equipment as they are relatively inexpensive, easy to operate, and produce a wide range of particle sizes. Bitra et al., (2009) and Soucek et al., (2007) indicated that size reduction is an important unit operation for reducing the particle sizes of biomass material for thermal gasification.
In a study conducted by Yancey et al., (2014) grinding energy and particle size were compared at varying feedstock moisture contents. Grinding energy for corn stover, switch grass and wheat straw were compared at moisture contents of $10-25 \%$ in $5 \%$ increments. Grinding energy for corn stover and switch grass showed a steep increase as moisture increased. Moisture content in straw had less effect on grinding energy, although the same pattern was observed. Operating speed, moisture content and initial particle size appear to be crucial in minimizing effective specific energy requirements for biomass size reduction.

Keeping the above facts in view, the present study was conducted to assess the energy requirement for cutting of selected biomass feedstock viz., pigeon pea stalk, cotton stalk and vilaytee babool and to determine the properties of biomass for thermal gasification.

\section{Materials and Methods}

\section{Biomass feedstock}

The required size of cotton stalk, pigeon pea stalk and Vilaytee babool woods were collected from the Main Agricultural Research Station (MARS), Raichur. These biomass materials had higher length and diameter. Hence, there was a need to reduce the length of cotton stalk, pigeon pea stalk and Vilaytee babool wood. The experiments were carried out with three different particle sizes viz., 25-50, 50-75 and 75-100 $\mathrm{mm}$ of length.

Since these biomass materials used for entire study was collected once from only single site and all the samples with different size were stored in plastic container for experiments, composition and properties were assumed same for all particle sizes. 


\section{Selection of size reduction machine}

There is a need to reduce the size of the stalk for feeding the biomass to the gasifier. Hence, a size reduction machine available in the Department of Farm Machinery and Power Engineering at College of Agricultural Engineering, Raichur was used to reduce the size of biomass material (Plate 1).

Ghaly et al., (2013) evaluated the performance of straw chopping system for fluidized bed gasifier. The power required for cutting of straw varied from a low 3.69 to $5.02 \mathrm{Hp}$, when the speed of the cutting blade was changed from 800 to $2500 \mathrm{rpm}$. So that biomass cutting machine was selected and it as driven by 4 HP motor consisted of D handle, wheel locking system, cutting blade assembly, compression spring, and power transmission system for cutting blade adjusting unit. It had salient features like simple in construction, provision for adjusting the length of cut and speed of operation.

\section{Performance evaluation of size reduction machine}

The size reduction machine was evaluated for its performance of moisture content at below 10 per cent and three different lengths of cut 25-50, 50-75 and 75-100 mm. The performance of machine was compared with manual cutting using an axe as control.

The cotton stalk, pigeon pea stalk and Vilaytee babool wood collected were sun dried to achieve moisture content below 10 per cent. The stalk was tied into small size sized bundles, so that an operator can hold these bundles of stalk in handful and cut easily.

The following initial adjustments were made on the machine before starting the cutting of stalk and wood. The wheel locking lever was adjusted to the required speed of cutting blade and metal cutting blade was replaced with the wood cutting blade.

A single phase energy meter was connected in between the wire connection from board and size reduction machine to measure the electric energy consumption during the cutting operation. After making the initial adjustments as required for smooth operation of machine, the machine was started and the material was fed to the machine. During cutting, the time required to cut the known weight of biomass material to the required length was recorded simultaneously using the digital stop watch.

The electrical energy consumed by the machine was also measured using a single phase energy meter. To compare the machine performance with manual cutting, an experienced labour was engaged and asked to cut a known weight of sample using an axe. The time required to cut the known weight of sample to the required length of biomass was recorded. The above procedure was repeated at different levels of moisture content and length of cut of different biomass material.

\section{Characteristics of selected biomass material for thermal gasification}

The physical, chemical and thermal properties of agricultural and forest biomass material viz., moisture content, bulk density, volatile matter content, ash content and fixed carbon content was determined using hot air oven, muffle furnace apparatus by using the ASTM D3173-11 and ASTM D/3175-11 standard test procedure (Ahmad et al., 2013), Shinde and Singarvelu (2014) and (Rao et al., 2004). The calorific value of the different biomass material was determined by digital bomb calorimeter according Indian standards (IS: $1359 ; 1959)$. 


\section{Results and Discussion}

\section{Cutting capacity}

The performance characteristics of size reduction machine at different lengths of cut with average cutting capacity and energy consumption in comparison with manual cutting for pigeon pea stalk, cotton stalk and vilaytee babool biomass material was evaluated.

The average cutting capacity of pigeon pea stalk machine at 3.28 per cent moisture content was maximum $\left(32.13 \mathrm{~kg} \mathrm{~h}^{-1}\right)$ for 75 $100 \mathrm{~mm}$ length of cut and it was minimum (21.35 $\mathrm{kg} \mathrm{h}^{-1}$ ) for $25-50 \mathrm{~mm}$ lengths of cut. The average cutting capacity of cotton stalk at 6.98 per cent moisture content was maximum $\left(24.12 \mathrm{~kg} \mathrm{~h}^{-1}\right)$ with $75-100 \mathrm{~mm}$ lengths of cut and a minimum $\left(15.52 \mathrm{~kg} \mathrm{~h}^{-1}\right)$ for $25-50 \mathrm{~mm}$ lengths of cut. Whereas maximum average cutting capacity of $39.40 \mathrm{~kg} \mathrm{~h}^{-1}$ was recorded for Vilaytee babool at 9.45 per cent moisture content with $75-100 \mathrm{~mm}$ length of cut and a minimum of $25.04 \mathrm{~kg} \mathrm{~h}^{-1}$ with $25-50 \mathrm{~mm}$ length of cut (Table 1).

Variation in cutting capacity for different feed material may be due to the percentage of moisture content present in the biomass and the different lengths of cut. As the length of cut increased, the time required to cut a given mass decreased resulting in higher cutting capacity of machine. At higher moisture content of biomass material, cutting capacity increased due to fast cutting action of section of material (Yancey et al., 2014).

The average capacity of cutting of pigeon pea stalk by manually at 3.28 per cent moisture content was maximum $\left(8.55 \mathrm{~kg} \mathrm{~h}^{-1}\right)$ for 75 $100 \mathrm{~mm}$ length of cut and it was minimum $\left(4.58 \mathrm{~kg} \mathrm{~h}^{-1}\right)$ for $25-50 \mathrm{~mm}$ lengths of cut.
While the average capacity of cutting of cotton stalk at

6.98 per cent moisture content was maximum $\left(11.40 \mathrm{~kg} \mathrm{~h}^{-1}\right)$ for $75-100 \mathrm{~mm}$ lengths of cut and it was minimum $\left(6.40 \mathrm{~kg} \mathrm{~h}^{-1}\right)$ for $25-50$ $\mathrm{mm}$ lengths of cut. Whereas maximum average capacity of cutting $\left(15.42 \mathrm{~kg} \mathrm{~h}^{-1}\right)$ was recorded for Vilaytee babool at 9.45 per cent moisture content for 75-100 mm lengths of cut and it was minimum $\left(8.20 \mathrm{~kg} \mathrm{~h}^{-1}\right)$ for 25 $50 \mathrm{~mm}$ lengths of cut (Table 1).

By comparing the two methods of cutting, the capacity of cutting increased with increase in moisture content for machine, while in case of manual cutting the capacity of cutting increased with increase in moisture content. This may be due to forces applied during cutting. In case of machine cutting uniform tangential force was applied, while in manual cutting impact force was applied. Hence, two cutting capacities were obtained in two methods of cutting.

\section{Energy consumption}

The total energy consumption for cutting of pigeon pea stalk by machine at 3.28 per cent moisture content was maximum $\left(0.13 \mathrm{MJ} \mathrm{kg}^{-}\right.$ ${ }^{1}$ ) for $75-100 \mathrm{~mm}$ lengths of cut and it was minimum (0.06 $\mathrm{MJ} \mathrm{kg}{ }^{-1}$ ) for 25-50 mm lengths of cut.

While, the total energy consumption for cutting of cotton stalk at 6.98 per cent moisture content was maximum $\left(0.19 \mathrm{MJ} \mathrm{kg}^{-}\right.$ ${ }^{1}$ ) for $75-100 \mathrm{~mm}$ lengths of cut and it was minimum (0.09 $\mathrm{MJ} \mathrm{kg}{ }^{-1}$ ) for 25-50 mm lengths of cut. Whereas maximum total energy consumption for cutting of $0.23 \mathrm{MJ}$ $\mathrm{kg}^{-1}$ was recorded for Vilaytee babool at 9.45 per cent moisture content for $75-100 \mathrm{~mm}$ lengths of cut and it was minimum of $0.06 \mathrm{MJ}$ $\mathrm{kg}^{-1}$ for 25-50 mm lengths of cut (Table 1). 
Table.1 Performance evaluation of size reduction machine with comparison of manual method

\begin{tabular}{|c|c|c|c|c|c|c|c|c|c|c|c|}
\hline \multirow{2}{*}{$\begin{array}{l}\text { Sl. } \\
\text { No. }\end{array}$} & \multirow{2}{*}{$\begin{array}{l}\text { Types of } \\
\text { biomass } \\
\text { material }\end{array}$} & \multirow{2}{*}{$\begin{array}{c}\text { Moisture } \\
\text { content } \\
\text { (per cent) }\end{array}$} & \multirow{2}{*}{$\begin{array}{c}\text { Size of } \\
\text { biomass } \\
\text { material } \\
(\mathbf{m m})\end{array}$} & \multicolumn{6}{|c|}{ Size reduction machine } & \multicolumn{2}{|c|}{ Manual method } \\
\hline & & & & $\begin{array}{c}\text { Average } \\
\text { Cutting } \\
\text { capacity } \\
\left(\mathbf{k g ~ h}^{-1}\right)\end{array}$ & $\begin{array}{c}\text { Energy } \\
\text { meter } \\
\text { reading } \\
(\mathrm{kW})\end{array}$ & $\begin{array}{c}\text { Human } \\
\text { power } \\
(\mathbf{k W})\end{array}$ & $\begin{array}{c}\text { Total } \\
\text { power } \\
(\mathrm{kW})\end{array}$ & $\begin{array}{c}\text { Total } \\
\text { energy } \\
\text { consumed } \\
\left(\mathrm{kWh} \mathrm{kg}^{-1}\right)\end{array}$ & $\begin{array}{c}\text { Energy } \\
\text { consumed } \\
\left(\mathrm{MJ} \mathrm{kg}^{-1}\right)\end{array}$ & $\begin{array}{c}\text { Cutting } \\
\text { capacity } \\
\left(\mathbf{k g ~ h}^{-1}\right)\end{array}$ & $\begin{array}{c}\text { Human } \\
\text { energy } \\
\text { consumed } \\
\left(\mathrm{MJ} \mathrm{kg}^{-1}\right)\end{array}$ \\
\hline \multirow[t]{3}{*}{1} & \multirow{3}{*}{$\begin{array}{c}\text { Pigeon } \\
\text { pea stalk }\end{array}$} & \multirow[t]{3}{*}{3.28} & $25-50$ & 21.35 & 0.69 & 0.0735 & 0.76 & 0.04 & 0.14 & 4.58 & 1.21 \\
\hline & & & $50-75$ & 28.00 & 0.53 & 0.0735 & 0.60 & 0.02 & 0.07 & 6.19 & 1.64 \\
\hline & & & $75-100$ & 32.13 & 0.47 & 0.0735 & 0.54 & 0.01 & 0.04 & 8.55 & 2.26 \\
\hline \multirow[t]{3}{*}{2} & \multirow{3}{*}{$\begin{array}{c}\text { Cotton } \\
\text { stalk }\end{array}$} & \multirow[t]{3}{*}{6.98} & $25-50$ & 15.52 & 0.75 & 0.0735 & 0.82 & 0.05 & 0.16 & 6.40 & 1.70 \\
\hline & & & $50-75$ & 20.34 & 0.63 & 0.0735 & 0.70 & 0.03 & 0.10 & 8.32 & 2.20 \\
\hline & & & $75-100$ & 24.12 & 0.55 & 0.0735 & 0.62 & 0.02 & 0.07 & 11.40 & 3.01 \\
\hline \multirow[t]{3}{*}{3} & \multirow{3}{*}{$\begin{array}{c}\text { Vilaytee } \\
\text { babool }\end{array}$} & \multirow[t]{3}{*}{9.45} & $25-50$ & 25.04 & 1.51 & 0.0735 & 1.58 & 0.06 & 0.21 & 8.20 & 2.17 \\
\hline & & & $50-75$ & 33.51 & 0.96 & 0.0735 & 1.03 & 0.03 & 0.10 & 11.23 & 2.97 \\
\hline & & & $75-100$ & 39.40 & 0.63 & 0.0735 & 0.70 & 0.02 & 0.07 & 15.42 & 4.08 \\
\hline
\end{tabular}

Table.2 Physical properties of selected biomass material

\begin{tabular}{|c|c|c|c|c|c|c|}
\hline Sl. No. & $\begin{array}{c}\text { Types of biomass } \\
\text { material }\end{array}$ & $\begin{array}{c}\text { Size of biomass } \\
\text { material (mm) }\end{array}$ & $\begin{array}{l}\text { Diameter } \\
(\mathbf{m m})\end{array}$ & $\begin{array}{l}\text { Moisture content } \\
\text { (per cent) }\end{array}$ & $\begin{array}{l}\text { Total solids } \\
\text { (per cent) }\end{array}$ & $\begin{array}{l}\text { Bulk density } \\
\quad\left(\mathrm{kg} \mathrm{m}^{-3}\right)\end{array}$ \\
\hline \multirow{3}{*}{1} & \multirow{3}{*}{ Pigeon pea stalk } & $25-50$ & 6-10 & \multirow{3}{*}{3.28} & \multirow{3}{*}{96.72} & \multirow{3}{*}{501} \\
\hline & & $50-75$ & $6-14$ & & & \\
\hline & & $75-100$ & $6-18$ & & & \\
\hline \multirow{3}{*}{2} & \multirow{3}{*}{ Cotton stalk } & $25-50$ & $5-10$ & \multirow{3}{*}{6.98} & \multirow{3}{*}{93.02} & \multirow{3}{*}{465} \\
\hline & & $50-75$ & $6-13$ & & & \\
\hline & & $75-100$ & $6-16$ & & & \\
\hline \multirow{3}{*}{3} & \multirow{3}{*}{ Vilaytee babool } & $25-50$ & $11-18$ & \multirow{3}{*}{9.45} & \multirow{3}{*}{90.55} & \multirow{3}{*}{556} \\
\hline & & $50-75$ & $18-26$ & & & \\
\hline & & $75-100$ & $18-46$ & & & \\
\hline
\end{tabular}


Table.3 Chemical and thermal properties of selected biomass material

\begin{tabular}{|c|c|c|c|c|c|c|}
\hline Sl. No. & $\begin{array}{c}\text { Types of biomass } \\
\text { material }\end{array}$ & $\begin{array}{c}\text { Size of } \\
\text { biomass } \\
\text { material } \\
\text { (mm) }\end{array}$ & $\begin{array}{c}\text { Volatile } \\
\text { matter } \\
\text { (per cent) }\end{array}$ & $\begin{array}{c}\text { Ash } \\
\text { content } \\
(\text { per cent) }\end{array}$ & $\begin{array}{c}\text { Total } \\
\text { carbon } \\
\text { content } \\
\text { (per cent) }\end{array}$ & $\begin{array}{c}\text { Calorific } \\
\text { value } \\
\left(\mathbf{M J ~ k g}^{-1} \mathbf{)}\right.\end{array}$ \\
\hline $\mathbf{1}$ & Pigeon pea stalk & $25-100$ & 80.67 & 1.39 & 17.94 & 16.44 \\
\hline $\mathbf{2}$ & Cotton stalk & $25-100$ & 80.20 & 1.43 & 18.37 & 16.05 \\
\hline $\mathbf{3}$ & Vilaytee babool & $25-100$ & 80.81 & 1.83 & 17.36 & 17.49 \\
\hline
\end{tabular}

Plate.1 A view of biomass cutting operation

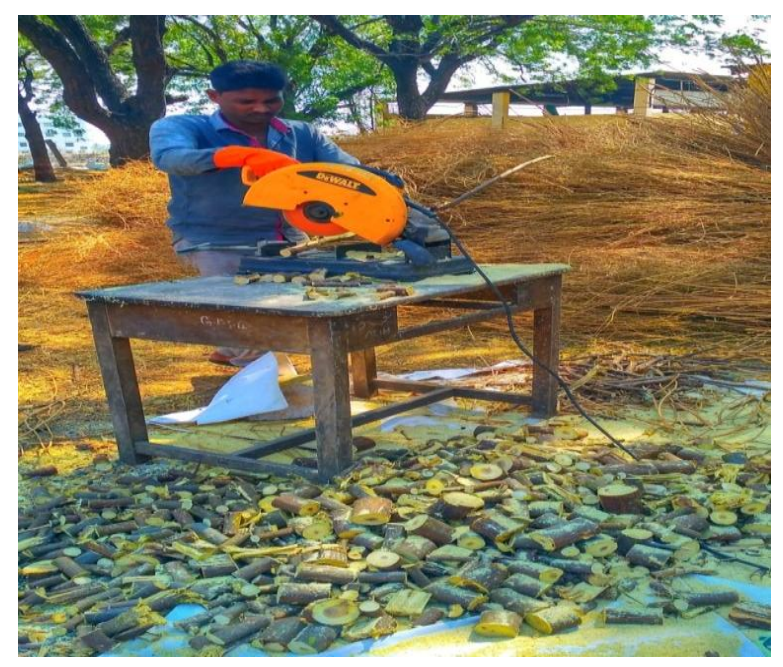

The total energy consumption for cutting of pigeon pea stalk manual at 3.28 per cent moisture content was maximum $\left(2.26 \mathrm{MJ} \mathrm{kg}^{-}\right.$ ${ }^{1}$ ) for $75-100 \mathrm{~mm}$ lengths of cut and it was minimum (1.21 MJ kg-1) for 25-50 mm lengths of cut. While, the total energy consumption for cutting of cotton stalk at 6.98 per cent moisture content was maximum (3.01 $\mathrm{MJ} \mathrm{kg}^{-1}$ ) for 75-100 mm lengths of cut and it was minimum (1.69 $\mathrm{MJ} \mathrm{kg}^{-1}$ ) for $25-50 \mathrm{~mm}$ lengths of cut. Whereas maximum total energy consumption of $4.08 \mathrm{MJ} \mathrm{kg}^{-1}$ was recorded for cutting of Vilaytee babool at 9.45 per cent moisture content for $75-100 \mathrm{~mm}$ lengths of cut and it was minimum of $2.17 \mathrm{MJ}$ $\mathrm{kg}^{-1}$ for 25-50 mm lengths of cut (Table 1). The size reductions of biomass material are demanding due to the fibrous and tenacious nature of their structure. The energy consumption of size reduction machine depends on the certain factors including the initial particle size of the biomass, moisture content, biomass feed rate, biomass properties and the machine variables. This might be due to the energy consumption with different length of cut was maximum for Vilaytee babool and a minimum for pigeon pea stalk, these findings are similar to findings of Anukam et al., (2016).

\section{Physico-chemical and thermal properties of selected biomass material}

\section{Physical properties}

The physical properties of selected biomass material are presented in Table 2. The diameter of cotton stalk, pigeon pea stalk and Vilaytee babool wood varied from 6-15, 6-17 and $15-30 \mathrm{~mm}$, respectively. The length of 
feed stock material ranged from $25-100 \mathrm{~mm}$ for all the biomass material. The moisture content of dried samples recorded was 3.28, 6.98 and 9.45 per cent for pigeon pea stalk, cotton stalk and Vilaytee babool, respectively. The percentage total solid for pigeon pea stalk, cotton stalk and Vilaytee babool was found to be $96.72,93.02$ and 90.55 per cent, respectively. The variation in percentage of total solids in biomass material may be due to the variations in percentage of moisture content of the feed stock material. The bulk density of 501,465 and $556 \mathrm{~kg} \mathrm{~m}^{-3}$ was observed for pigeon pea stalk, cotton stalk and Vilaytee babool, respectively which depended on the moisture content in biomass materials. The findings are in close agreement with the results of Rao et al., (2004), Mishra et al., (2010) and Power et al., (2014).

\section{Chemical and thermal properties}

The chemical and thermal properties of selected biomass material are presented in Table 3. The volatile solids content of 80.20 , 80.67 and 80.81 per cent were recorded for pigeon pea stalk, cotton stalk and Vilaytee babool, respectively. The ash content of pigeon pea stalk, cotton stalk and Vilaytee babool were found to be $1.43,1.39$ and 1.83 per cent, respectively. The fixed carbon content of pigeon pea stalk, cotton stalk and Vilaytee babool were found to be 18.37 , 17.94 and 17.36 per cent, respectively. The calorific value of different biomaterials like pigeon pea stalk, cotton stalk and Vilaytee babool were $16.44,16.05$ and $17.49 \mathrm{MJ} \mathrm{kg}^{-1}$, respectively. The results are closely agreed with the reported value (Samodini et al., 2013).

In conclusions, the size reduction machine for cutting of selected biomass feedstock was evaluated. The performance characteristics of cutting capacity and energy consumption of biomass for different biomass material were determined. The capacity of cutting of biomass material by machine was maximum (39.40 $\mathrm{kg} \mathrm{h}^{-1}$ ) for Vilaytee babool at 9.45 per cent moisture content with 75-100 mm length of biomass and a minimum of $15.52 \mathrm{~kg} \mathrm{~h}^{-1}$ for cotton stalk at 6.98 per cent moisture content with 25-50 mm length of biomass compared with manual cutting. Variation in cutting capacity for different feed material may be due to the percentage of moisture content present in the biomass and the different lengths of cut. The energy consumption of biomass material by using machine was maximum $\left(0.21 \mathrm{MJ} \mathrm{kg}^{-1}\right)$ for Vilaytee babool at 9.45 per cent moisture content with $25-50$ $\mathrm{mm}$ length of biomass and a minimum of 0.04 $\mathrm{MJ} \mathrm{kg}^{-1}$ for pigeon pea stalk at 3.28 per cent moisture content with 75-100 mm length of biomass compared with manual. The energy consumption of size reduction machine depends on the certain factors including the initial particle size of the biomass, moisture content, biomass feed rate, biomass properties and the machine variables.

\section{References}

Ahmad, F., Daud, A. W., Ahmad, M. A. and Radzi, R., 2013, The effects of acid leaching on porosity and surface functional groups of cocoa shell based activated carbon. Chem. Engg. Res. Des., 91(6): 1028-1038.

Anonymous, 2000, FAO Corporate Document Repository. Chapter V. Hay crops cereals and grasses. In: FAO plant production and protection series. Pp. 1-315. Available from: http://www.fao. Org.

Anukam, A., Mamphweli, S., Reddy, P., Meyer, E. and Okoh, O., 2016, Preprocessing of sugarcane bagasse for gasification in a downdraft biomass gasifier system: A comprehensive review. Renew., Sust. Ener. Rev., 66(3):775-801. 
Bitra, V. S. P., Womac, A. R., Chevanan, N., Miu, P. I., Igathinathane, C. and Sokhansanj, S., 2009, Direct mechanical energy measures of hammer mill comminution of switchgrass, wheat straw, and corn stover and analysis of their particlesize distributions. Powder Technology, 193: 32-45.

Cundiff, J. S. and Grisso, R. D., 2008, Containerized handling to minimize hauling cost of herbaceous biomass. Bio. Bioen., 32: 308-313.

Ghaly, A. E., Ergudenler, A., Suhaibani, S. Al. and Ramakrishnaan, V. V., 2013, development and evaluation of straw chopping system for fluidized bed gasifier. Int. J. Engg. Scie., 2(10): 97110.

Hess, J. R., Kenney, K. L., Ovard, L. P., Searcy, E. M. and Wright, C. T., 2009, Uniform-format solid feedstock supply system: a commodity-scale design to produce an infrastructure compatible bulk solid from lignocellulosic biomass. Idaho Falls, Idaho: Idaho National Laboratory. Report No. INL/EXT-08-14752.

Hess, J. R., Wright, C. T. and Kenney, K. L., 2007, Cellulosic biomass feed stocks and logistics for ethanol production. Biofuel. Bioprod. Bior., 1: 181-190.

Kumar, P., Barrett, D. M., Delwiche, M. J. and Stroeve, P., 2009, Methods of pretreatment of lignocellulosic biomass for efficient hydrolysis and biofuel production. Ind. Eng. Chem. Res. 48: 3713-29.

Mani, S., Tabil, L. G. and Sokhansanj, S., 2004, Grinding performance and physical properties of wheat and barley straws, corn stover, and switchgrass. Bio. Bioen., 27: 339-52.

Mishra, P., Singh, P. and Baredar, P., 2010, Impact of moisture level in atmosphere on biomass gasification a bio energy for sustainable development. Int. J. Envir. Sci., 1(4): 640-644.

Oasmaa, A., Kyto, M. and Sipila, K., 2001, Pyrolysis oil combustion tests in an industrial boilers. In: Bridgwater AV, editor. Progress in thermochemical biomass conversion. Oxford: Blackwell Science, p: 1468-81.

Powar. R, Bandgar, P.S. and Kadu, P., 2014, Studied the clean energy from cotton stalk exercise of cook stove. Int. J. Emer. Tech. and Advanc. Engg., 4(7): 469-474.

Rao, M. S., Singh, S. P., Sodha, M. S., Dubey, A. K. and Shyam, M., 2004, Stoichiometric, mass, energy and energy balance analysis of counter current fixed bed gasification of postconsumer residues. Bio. Bioe., 27(2): 155-171.

Samodini, S., Chittaranjan, S. N. and Sandip, G. K., 2013, Studies on characterisation of biomass fuel. Int. J. Agri. Engg., 6(2): 547-551.

Shinde, V. B. and Singarvelu, M., 2014a, Thermo gravimetric analysis of biomass stalks for briquetting. J. Envi. Res. Dev., 9(1): 151-160.

Soucek, J., Kocanova, V. and Novak, M., 2007 Parameters of energy crop biomass handling. Res. Agric. Engg., 53: 161-165.

Tavakoli, H., Mohtasebi, S. S., Jafari, A. and Mahdavinejad, D., 2009, Power requirements for particle size reduction of wheat straw as a function of straw threshing unit parameters. Aust. J. Crop. Sci., 3(4): 231-36.

Wei, L., Pordesimo, L. O., Igathinathane, C. and Batchelor, W. D., 2009, Process engineering evaluation of ethanol production from wood through bioprocessing and chemical catalysis. Bio. Bioen., 33: 255-66. 
Wendt, L., Delwiche, M., Ray, A., Gresham, G. and Hess, J. R., 2008, Critical supply chain issues: quality factors, moisture management, and logistics. In: International conference on sorghum for biofuels. Houston, Texas, USA. Available from: http://www.ars.usda.gov. August 1922.

Wu, X., Zhao, R., Bean, S. R., Seib, P. A.,
McLaren, J. S., Madl, R. L., 2007, Factors impacting ethanol production from grain sorghum in the dry-grind process. Cereal Chem., 84: 130-136. Yancey, N., Wright, C. T. and Westover, T. L., 2014, Optimizing hammer mill performance through screen selection and hammer design. Boifuels, 4(1) 8594.

\section{How to cite this article:}

Manjunath, H., Vijayakumar Palled, M. Veerangouda, Devanand Maski and Ramachandra, C.T. 2019. Cutting Energy Assessment of Selected Biomass Materials as Feedstock for Gasification. Int.J.Curr.Microbiol.App.Sci. 8(06): 1092-1100.

doi: https://doi.org/10.20546/ijcmas.2019.806.135 